\title{
The contribution of digitalisation to business longevity from a competitiveness perspective
}

\author{
Chiara Rossato and Paola Castellani \\ Department of Business Administration, University of Verona, Verona, Italy
}

\begin{abstract}
Purpose - This paper aims to examine how long-lived firms can further develop through digitalisation in terms of actions, conditions and effects from a competitiveness perspective.

Design/methodology/approach - This exploratory study follows an inductive approach based on a survey conducted via interviews undertaken with nine long-lived Italian firms. The dimensions of the model (command, continuity, community, connection), elaborated by Miller and Le Breton-Miller (2005) in relation to longevity factors, were chosen to analyse digitalisation's contribution to these long-lived firms' development. Findings - The digitalisation implemented by the analysed firms contributed in a variety of ways: (1) improved the efficiency and effectiveness of their business processes, (2) enhanced the understanding of customer experience, (3) supported their craftsmanship and the transmission of the knowledge included in the entrepreneurial path, (4) increased the awareness of the cultural value of the firms' heritage and (5) allowed for the development of cutting-edge design skills by experimenting with content on different digital platforms and devices.

Practical implications - This study suggests managers of long-lived firms develop digital skills that allow them to interact with the rapid evolution of this context and understand how to effectively implement digitalisation in their specific firm. From this perspective, it is strategic to establish or strengthen collaborative network relationships to acquire such necessary skills.

Originality/value - This study provides novel empirical evidence on how long-lived firms are facing the challenge of digitalisation in terms of actions, conditions and effects to improve their competitiveness and ensure their survival.
\end{abstract}

Keywords Long-lived firms, Entrepreneurship, Innovation/tradition relationship, Digital manufacturing, Craftsmanship, Corporate competitiveness

Paper type Research paper

\section{Introduction}

In the current economic context, long-lived firms are those that have developed at the global level. This extension to the global scale is evidenced by numerous initiatives that have proliferated over time, primarily in the form of the establishment of international groups such as the global "Les Hénokeins", the London-based "Tercentenarians Club" (Stadler, 2011), the Japanese "Shinise" (Iwasaki and Kanda, 1996; Krahnke, 2018) and the Italian "Union of Italian Centenarian Enterprises" (Listri, 2006) and "The Centenarians" (Napolitano and Marino, 2014).

In the last decade, such firms have significantly increased in number, especially in Japan and Italy. According to a nationwide Japanese survey (Tokyo Shoko Research, 2009), there were more than 21,000 firms older than 100 years at the end of September 2009, while in 2019, Teikoku Data Bank counted over 33,000 businesses in Japan to be over a century old (Lufkin, $2020)-51.14 \%$ growth over the decade. For Italy, the only country in the world to have established a National Register of Italian Historic Firms, at the end of 2012, the number of

(C) Chiara Rossato and Paola Castellani. Published by Emerald Publishing Limited. This article is published under the Creative Commons Attribution (CC BY 4.0) licence. Anyone may reproduce, distribute, translate and create derivative works of this article (for both commercial and non-commercial purposes), subject to full attribution to the original publication and authors. The full terms of this licence may be seen at http://creativecommons.org/licences/by/4.0/legalcode

Digitalisation and business longevity

Received 24 February 2020 Revised 24 March 2020 Accepted 24 March 2020

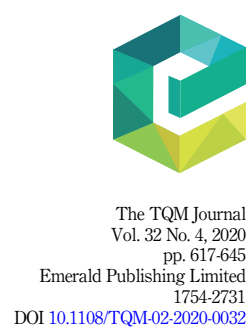


TQM

32,4

618

long-established firms was 2,227 ; this had increased to 2,555 by $2019-14.73 \%$ growth over the seven years. These data are even more significant in light of the economic and financial crisis that began in 2007 and has affected the whole world, including Japan and Italy.

The fervour around long-lived firms and their increased number has led to growing interest from scholars from different disciplines in the topic of business longevity, especially since the late 1990s, such that long-lived firms can be considered an interdisciplinary topic. In particular, in addition to the initial economic and sociological studies (e.g. Bates, 1990; Brüdler et al., 1992), the published research on business longevity has primarily covered the disciplines of management (e.g. De Geus, 1997; Miller and Le Breton-Miller, 2005; Reader and Watkins, 2006; Schildt et al., 2006; Burgelman and Grove, 2007; Desai et al., 2008; Zellweger and Sieger, 2012; De Massis et al., 2016; Erdogan et al., 2019) and business history (e.g. Cassis, 1997; Fridenson, 2004; Colli, 2013; Kansikas, 2015; Amankwah-Amoah et al., 2017).

With reference to the management field - the specific subject of this paper - studies are primarily related to a family business, entrepreneurship and strategy research (Riviezzo et al., 2015a). More specifically, they focus on the conditions that allow some firms to survive and to perpetuate their businesses despite facing the multiple crises and challenges that dot the history of any country over the course of time. In other words, many scholars (Peter and Waterman, 1982; Collin and Porras, 1994; De Geus, 1997; Foster and Kaplan, 2001; Albrecht, 2003; Ward, 2004; Miller and Le Breton-Miller, 2005; Fahed-Sreid and Djounddourian, 2006; Marcus, 2006; Stadler, 2007, 2011; Bakr et al., 2009; Riviezzo et al., 2015b; Galadanchi and Bakar, 2018) have deeply explored business longevity to identify the so-called "longevity factors" that support the development and the competitiveness of a firm over the long term.

These firms, in fact, have overcome multiple critical issues, such as two industrial revolutions, two world wars, globalisation and world economic crises in 1929, 1973 and 2007, by continuing their activities and maintaining competitiveness. A further and overwhelming challenge that long-lived companies increasingly face in the current competitiveness context is digitalisation. This topic has been studied from different perspectives, including the technological standpoint (Liao et al., 2017), and scholars have highlighted its potential benefits in terms of cost reduction, productivity, quality, customer satisfaction and even healthcare and environmental performance (Kolberg and Zühlke, 2015; Lu, 2017).

In spite of scientific contributions on digitalisation increasing, very few studies analyse how long-lived firms face this challenge (e.g. Hicks and Hegde, 2005; Sharma and Dixit, 2017; Erdogan et al., 2019); in particular, there is scant empirical evidence in the management literature on how digitalisation can contribute to enhancing long-lived firms' competitiveness and enable them to continue to survive over time.

For filling this gap, this paper aims to examine the contribution of digitalisation to long-lived firms' development. More specifically, it explores how long-lived firms can further develop through digitalisation in terms of actions, conditions and effects from a competitiveness perspective.

Given the limited literature on business longevity and digitalisation, this study is explorative in nature. As such, it adopts an inductive approach to examine the specific case of long-lived Italian enterprises.

This paper is organised as follows. After providing a literature review on business longevity, especially longevity factors, and the way in which long-established firms face the challenges of digitalisation, the study method is presented. Following this, the main results are highlighted and discussed. The paper concludes by proposing theoretical and managerial implications, as well as limitations and future research directions.

\section{Theoretical background}

2.1 Business longevity factors

Business longevity is characterised by the multidisciplinary nature of the approaches adopted to study this topic (Napolitano et al., 2015); nevertheless, business history and 
management studies are the two predominant streams greatly affecting the theoretical development of such research (Riviezzo et al., 2015a). This scientific literature is focused mainly on identifying critical success factors - also known as longevity factors - via which a firm can build and expand its competitive advantage over time.

Most studies on business longevity over the last three decades have emerged from management scholars, especially those engaged in a family business, entrepreneurship and strategic management research (Riviezzo et al., 2015a). Management scholars have adopted two different approaches to the study and identification of factors supporting firm longevity: one in which a holistic approach (i.e. seeking to identify all drivers that support the survival and competitiveness of a firm over the long term) is adopted, and one that focuses on the evaluation of the influence of a single factor on business development and longevity.

The first category was particularly prevalent at the beginning of research on the topic; more recent contributions in this vein have aimed to refine what was already published up to the first decade of the 21st century (i.e. Peter and Waterman, 1982; Collin and Porras, 1994; De Geus, 1997; Collins, 2000; Foster and Kaplan, 2001; Marcus, 2006; Stadler, 2007, 2011). They comprise mostly contributions published in books, with only the most recent being journal articles. These studies mainly list factors relating to (1) the characteristics of the family business and its peculiarities (such as, for example, the relationship between business and family and the problem of generational change (e.g. Aronoff, 2004; Tàpies and Moya, 2012)); (2) the characteristics of the entrepreneur with reference to his or her role as the leader of the longestablished enterprise (e.g. Zellweger et al., 2012); and (3) the main organisational and strategic choices capable of strengthening competitiveness over time and ensuring business continuity (e.g. McDowell et al., 2016). Many of these studies have been deepened by considering different regional and cultural contexts. Several have considered the US context (e.g. Ward, 2004; O'Hara, 2004; Miller and Le Bretton-Miller, 2005; Bakr et al., 2009; Densil and Oniel, 2010), while others have studied family firms in Japan (e.g. Funabashi, 2009; Goto, 2013; Sasaki and Sone, 2015; Krahnke et al., 2018), Lebanon (e.g. Fahed-Sreih and Djounddourian, 2006), China (e.g. Kim and Gao, 2013), Spain (e.g. Fernández Pérez and Puig, 2007) and Italy (e.g. Buzzavo and Gatti, 2012; Riviezzo et al., 2015b). This research, although pertaining to the experience of firms located in very different geographical and socio-cultural contexts, shows the existence of common elements. In essence, the longevity of family businesses depends on the health of their two constituent parts - the family and the company. Indeed, the longevity of these firms is closely connected to the commitment of the family, in two aspects. First, the commitment to building healthy interpersonal relationships between parents and children, and between siblings and in general between all members of the basic core of the entrepreneurial activity, such that each is aware of his or her role in the family and within the company. Second, the commitment to the continuity of the enterprise: (1) formulating and pursuing a stimulating and engaging mission, not based on just a desire for profit, but inspired by higher ideals; (2) favouring long-term relationships and collaboration with staff and business partners; and (3) providing adequate planning for generational transitions. Table 1 summarises the main results of these studies.

The second category focused on individual factors, has been prevalent during the last two decades and, in particular, over the last few years. Such work has almost always been published in the form of journal articles. These articles are mainly focused on the factors that have proven most critical for firm survival from a managerial point of view, including the planning of the generational change process (e.g. De Massis et al., 2008; Carney et al., 2014; Jaskiewicz et al., 2016; Parker, 2016; Wieccek-Janka et al., 2016; Houlder and Nandkishore, 2016), or that seem to exert great influence on the continuity and competitive development of the long-established company (e.g. the ability to combine the drive for innovation and enhancement of tradition). The most recent and important topic studied by scholars in this vein is the propensity to innovate of long-lived firms (e.g. De Massis et al., 2016; Filser et al., 2018; Erdogan et al., 2019). In particular, De Massis et al. (2016) conceptualised a new
Digitalisation and business longevity 
TQM 32,4

\section{0}

Author(s), year Longevity factors

Ward (2004)

O’Hara (2004)

Miller and Le Breton-Miller (2005)

Fahed-Sreih and

Djounddourian (2006)

Bakr et al. (2009)

Funabashi (2009)

(3) Process

(4) Parenting

(1) Family unity
The five insights, the major keys to the enduring success of family firms:

(1) We respect the challenge

(2) Family business issues are common and predictable, yet perspectives on the same issue will be different

(3) Communication is indispensable

(4) Planning is essential to the continuity

(5) Commitment is required of us

The four Ps to reduce or avert friction between family and business:

(1) Policies before the need for them

(2) Sense of purpose

(2) A product catering to basic human needs

(3) Primogeniture

(4) Role of women

(5) A commitment to continuing the legacy

(6) The use of adoption as a means to perpetuate family ownership

(7) Allowing the business rather than the family to come first

(8) An obligation to community and customer service

(9) Conflict arrangement

(10) Plan in writing

(11) System of governance

(1) Command (family-controlled businesses take command by acting as unfettered stewards rather than servants of shareholders)

(2) Continuity (family businesses pursue a lasting and substantive mission, not a monetary strategy)

(3) Community (family-controlled businesses have a "sticking", caring culture, not an internally competitive one. It is very selective, but once you are in, you are in for life)

(4) Connection (family businesses build connections by securing generous and longer-term relationships, not one-shot bargains. They are benevolent, responsive partners)

(1) Proper succession planning

(2) Proper planning for a healthy family relationship

(3) Openness and a liberal attitude towards accepting qualified successors, whether from within or outside the family

(1) High level of family involvement and commitment

(2) Effective succession process

(3) Family firm competitive advantage

(1) Leadership driven by clear values, vision and mission

(2) Long-term viewpoint and strategic approach

(3) The importance of people and a human merit system

(4) Customer orientation and building the economy

(5) Socially minded and building the nation

(6) Continuous innovation (change) and improvement

(7) Frugality and efficient use of natural resources

(8) Efforts to embody and generate culture/legacy
Table 1 .
Main publications on longevity factors product innovation strategy in family firms called innovation through tradition (ITT), and identified its underlying capabilities of interiorising and reinterpreting past knowledge. Erdogan et al. (2019) studied how family firms manage the tradition and innovation paradox that characterises their activity, and identified the new construct of temporal symbiosis as a firm's simultaneous adoption of retrospective and perspective approaches to the use of resources to continue with tradition but also generate innovation. 


\subsection{Digitalisation in long-lived firms}

Over the last five years, the topic of digitalisation, also known as digital transformation (Emily et al., 2015), has been extensively studied from a managerial perspective, with particular attention paid to manufacturing industries as the context in which the digital revolution has had - and continues to have - a significant impact. Terminologies such as cyber-physical systems, smart factories, the industrial revolution, the Internet of Things, production systems, manufacturing systems and smart manufacturing are used to refer to the current development of digitalisation across different manufacturing sectors (Liao et al., 2017).

In general, the digitalisation concept refers to a business model driven by "the changes associated with the application of digital technology in all aspects of human society" (Stolterman and Fors, 2004, p. 689). The technology usually implemented through digitalisation, from a corporate perspective, involves the ability to turn existing products into digital variants, which offer advantages over tangible products. This evolution can produce benefits in terms of more efficient business processes and flows, and therefore, better firm performance (Emily et al., 2015).

Over the last two decades, the challenges of digitisation have affected companies of all sizes (small, medium and large) and all ages (those established in the digital age and those founded in earlier periods, with the latter category also including long-lived firms).

The managerial literature on digitalisation in these firms has made few contributions. These studies can be divided into three categories according to the specific object of analysis: (1) digitalisation in long-lived small businesses, particularly highly innovative ones; (2) the behaviour of long-lived big companies in the face of the challenge of digitalisation; and (3) innovation to support the digital transformation process in long-lived firms.

Scholars of long-lived small firms considering the US context have labelled such firms "serial innovators" (Hicks and Breitzman, 2003; Leigh, 2002; Hicks and Hegde, 2005) and argued that they are often specialist suppliers in markets for technology. These innovative firms have survived beyond the entrepreneurial moment yet remain small (Taneja et al., 2016). Success in technology markets does not come easily and very few small firms survive. The survivors take advantage of that fact to produce technology likely to be more tradable in comparison with that of large firms, which is largely destined for in-house use. Compared with in-house technology, tradable technology is "higher quality, more general purpose, more broadly based, more basic, and more concentrated in newer generations of technology" (Hicks and Hegde, 2005, p. 703). Moreover, serial innovator firms are primarily creators of platform technologies or general-purpose technologies in general (Hicks and Hegde, 2005) and are prime candidates to develop industry standards, which facilitates the diffusion of their technologies across borders (Blind, 2001). In other words, markets for technologies help to explain the presence of "long-lived, highly innovative small firms" - an empirical reality in the US context - where "small" refers to the number of employees being no greater than 500 , "highly innovative" implies 15 or more USPTO patents registered between 1996 and 2000, and "long-lived" is defined as a firm surviving beyond the average life of companies in the sector (be it 25 or 50 or 100 years) (Hicks and Hegde, 2005). Although this last definition may seem imprecise, this arises because, in the managerial literature and practice, there is no shared concept of business longevity, although a significant number of scholars define the prerequisite for longevity as 100 years of business (Rossato, 2013).

Regarding the behaviour of long-lived big companies in the face of the challenge of digitalisation, Sebastian et al. (2017) focused on those whose success was built in the predigital economy and identified two digital strategies - customer engagement and digitised solutions - that provide direction for digital transformation. Moreover, they asserted that two technology-enabled assets are essential for executing those strategies: an operational backbone and a digital services platform. Under this framework, they described how a long-

Digitalisation and business longevity 
TQM

32,4

622

lived big company could combine these elements to navigate digital transformation. In particular, the study considered the new technologies called SMACIT (social, mobile, analytics, cloud and the Internet of Things). This acronym includes many digital technologies, such as artificial intelligence, blockchain, robotics and virtual reality. SMACIT is intended as shorthand for the entire set of powerful, readily accessible digital technologies. The study revealed three essential elements for a successful digital transformation: (1) clear definition of a digital strategy that guides leaders' efforts to create new value propositions by combining their companies' existing capabilities with those enabled by SMACIT and other digital technologies; (2) an operational backbone as the technology and business capabilities that ensure the efficiency, scalability, reliability, quality and predictability of core operations; and (3) a digital services platform as the technology and business capabilities that facilitate rapid development and implementation of digital innovations. The most proactive long-lived big companies in this research needed both "an operational backbone and a digital services platform to deliver the efficiency, reliability, speed and agility that the competitive environment demands. Although these two assets support very different business capabilities, they are complementary" (Sebastian et al., 2017, p. 204).

As regards innovation to support the digital transformation process in long-lived firms, scholars have tended to define the minimum threshold for company longevity as 100 years of continuous activity. Sharma and Dixit (2017, p. 1), in particular, analysing key factors for longevity in a detailed Japanese case study, observed that it is very important for this kind of firm to be conservative, asserting that "the pressure to exploit newer opportunities and invest resources to ward off potential threats is high, particularly in the digital era. However, longestablished firms are known to stay true to their core values and principles and usher in largescale radical changes very selectively". These considerations do not mean that longestablished firms must not consider digital transformation, which is affecting not only the economy but every dimension of life. The real suggestion is that firm survival must be preserved from any form of impulsive innovation guided by the current market or technological trends. Regarding the approach to innovation, Erdogan et al. (2019, p. 17) underlined that in some long-lived family firms, "current and new products and processes are segregated and treated as two different types of offerings". This behaviour is designed, on the one hand, to preserve the iconic products that mark the family's history, and on the other, to stimulate new product development and the digital impulses in this process. In this way, the long-lived family firm does not make changes to its iconic products but offers a wide range of new product lines using advanced technologies. This strategy allows these firms to combine innovation and tradition and remain competitive.

Given the increasing interest of scholars and practitioners in the topic of digitalisation and the scant attention paid to the contribution of digitalisation to long-lived firms' development, this study examines actions, conditions and effects of digitalisation on long-lived firms' competitiveness.

\section{Research method}

This exploratory study followed an inductive approach (Leitch et al., 2010) by performing a survey via interview undertaken to investigate the contribution of digitalisation to long-lived firms' development for the case of Italian firms. Given that this method is considered suitable "when a fresh perspective is needed" (Eisenhardt, 1989, p. 549), it was employed to make a solid contribution to the scant literature on this topic and, at the same time, draw more general conclusions.

This study adopted a purposive sampling approach, which involved the conscious selection of a small number of data sources meeting the following criteria: (1) firms that 
belong to the National Register of Italian Historic Firms, which includes firms of any legal form operating in any economic industry, registered on the business register and with uninterrupted exercise of their activity in the same industry for no less than 100 years; (2) participation in initiatives promoted by public and private institutions aiming to stimulate research on the longevity of business, especially regarding firms with an entrepreneurial culture of over 100 years; (3) Italian-owned firms that have been operating for more than 100 years; (4) firms that have faced at least two generational changes; (5) firms that are facing the digitalisation challenge; (6) firms that have long been established in national and international markets, regardless of their size; (7) firms that manufacture entirely in Italy; and (8) the relevance of the information available in relation to the research objectives.

With reference to the first criterion, the national Register of Italian Historic Firms - the only measurement tool for long-lived firms in Italy - includes 2,555 firms aged over 100 years (as of 31 December 2019), which operate across the following industries: commerce (31.62\%), industry $(24.46 \%)$, services $(17.45 \%)$, craftsmanship $(12.72 \%)$, agriculture $(9.71 \%)$ and other $(4.03 \%)$.

With regard to the second criterion, firms that participated in the national short film competition "Ancient Future" ("Futuro Antico"), promoted in July 2014 by Union of Italian Centenarian Enterprises, were selected. The "Futuro Antico" competition was selected for the two following reasons: (1) originality and importance of the project, which aimed to inform viewers via a short film on the history, cultural heritage, ethics, innovation, work and ability to adapt to the challenges of the future and the social dimension of long-lived Italian firms that are expressions of the quality and excellence of Made in Italy, and (2) inclusion of firms that are sources of stimulation and dissemination of research on an entrepreneurial culture extending more than 100 years.

Some 20 long-lived firms were identified, and their corporate websites examined in relation to their history, activities and values in order to verify all eight criteria listed above. Fifteen firms were identified as eligible targets. Using the tailored design survey method (Dillman et al.,2009), representatives of the 15 firms were contacted and requested to complete an email survey, containing a cover letter and a brief questionnaire. The cover letter clearly indicated the purpose and nature of the study, explained why the respondent's opinion was required and provided the respondent with information about his or her right to participate or withdraw at any time during the research. The questionnaire was aimed at understanding whether digitalisation is a tool that can contribute to the development of the firm. It was structured to collect data on the firm (name, location, foundation year, current entrepreneur or manager and core business) and its relationship with digitalisation (interpretation of the digitalisation challenge, types of digitalisation investment made and benefits achieved). Of the 15 firms, one reported that it had sold its core business to another firm and five communicated that they were not interested in participating in the research because of their corporate policy, discretion or lack of time. Thus, nine firms replied to the questionnaire.

After the survey was conducted, appointments for semi-structured in-depth interviews were set up with each respondent to collect detailed and personal opinions and experiences of the interviewees in line with the purpose of this research. A request was made for key informants who were available, knowledgeable on the topic of interest and "able to communicate about it" (Kumar et al., 1993, p. 1634). Entrepreneurs and top managers of the nine firms contacted made themselves available for the interview.

Table 2 shows the profiles of the firms examined in this study. Essentially, they had faced at least three generational changes and operated in sectors including industry (six), craftsmanship (two) and commerce (one).

On the basis of time and the availability of the interviewees (Flick, 2005), telephone interviews were conducted. This meant that emotions could not be captured; however, it decreased the risk of the interviewer affecting the interviewees' responses (Silverman, 2011).

Digitalisation and business longevity 
TQM

32,4

\section{4}

Each interview lasted 45-70 min. A semi-structured interview protocol was designed, as follows.

(1) Introduction:

- brief description of the aims of the research;

- the firm's history;

- the firm's mission and core business;

- the firm's values and corporate management;

- the relevance of digitalisation for the firm.

(2) How the firm is facing the digitalisation challenge:

- What was the role of the family and of the management in the challenge of digitalisation?

- How did employees accept the challenge of digitalisation?

- Have you faced this challenge in partnership with other stakeholders? Which stakeholders?

- What initiatives have you promoted and implemented?

- How did you support them?

- What benefits did you achieve through digital investments?

The interviews were audio recorded and later transcribed and checked for accuracy. For examining the data, content analysis was undertaken via NVivo 11 software. The coding of themes was inductively carried out (Saldana, 2015) in relation to the study's purpose to explore how long-lived firms may further develop from a competitiveness perspective through digitalisation. The themes that emerged were proposed by means of an analysis model identified within the longevity factors set out in the family business literature. This study, in particular, adopted the model elaborated by Miller and Isabel Le Breton-Miller (2005) on business longevity factors, including the four following dimensions: (1) command, referring to granting senior management considerable decision-making independence; (2) continuity, with regard to the maintenance of adherence to a farsighted mission; (3) community, in consideration of the development and unification of company culture with a deep concern for employees at all levels; and (4) connection, that is, establishing long-lived external relationships with clients and suppliers. While promoting the idea that all long-lived businesses should have certain common priorities, this model also recognises, and indeed requires that every firm independently configure those priorities to best match its selected strategy. This model was utilised for two reasons: (1) there are multiple models that identify longevity factors for family businesses, but management scholars do not agree on the identification of an exhaustive and precise model and (2) these dimensions capture and emphasise the behavioural characteristics and strategic decisions, digitalisation included, of the long-lived firms investigated in this study.

\section{Analysis and discussion of results}

\subsection{Command}

The respondents emphasised that the survival of the firm is strongly linked to the ability of those who guide it to adequately manage business succession, including timely identification 
Name, location in Italy
(foundation year)

Amarelli-Fabbrica di

Liquirizia dal 1731 di

Fortunato Amarelli

Rossano, Cosenza (1731)

Antica Dolceria Bonajuto

di Ruta F.

Modica, Ragusa (1880)

Manifattura Orafa Torrini Florence (1369)

Biscotti Gentilini

Roma (1890)
Number of generations

11

Core business and values

World leader in the field of pure licorice produced and marketed in metal packs; these have become collector items The firm has a long history of passion, culture and tradition. Ancient documents attest that by around $1500 \mathrm{AD}$, the Amarelli family already marketed the underground branches of locorice that still grows abundantly in its latifundia The Amarelli Museum received the "Guggenheim Business \& Culture Award" in 2001 and in 2004 the Italian Post Office recognised it, dedicating it a stamp issued in $3,500,000$ copies

$6 \quad$ For more than 150 years, the firm has been producing artisanal chocolate. It also makes sweets and nougats in the Modica and Sicilian tradition, mostly of Arab or Spanish origin

The firm started a revolutionary process of cultural recovery of ancient Hyblean recipes and of cold chocolate, a real gastronomic "fossil" that seemed destined to disappear

The Bonajuto-Ruta family made the passion for chocolate a business reality and is noted by Eurispes (Institute of Political, Economic and Social Studies) as among the 100 Italian Excellences, awarded and recognised internationally

24 The Antica Manifattura Orafa Torrini, led by Fabrizio Torrini, operates in the wake of its origins linked to the history of the goldsmith Torrini and to that of the Fabbrica branding that took place in Florence in 1369

New technological eras have brought construction and quality improvements, but the artisan and manufacturing expression, artistic creativity and the value of humanity and their traditions have not been abandoned

4 In 130 years of activity, the famous biscuit factory in Rome (Italy) has become a firm capable of preserving the link with tradition and craftsmanship. Over time, it has enriched and diversified its "workshop of taste" with highly successful products (dessert biscuits, rusks, shortbread, panettone and Easter pizza), tasted for generations and still loved for their authenticity and authenticity
Interviewed

Digitalisation and business longevity

CEO, President

Entrepreneur

Entrepreneur

General

manager
Table 2.

Profile of firms 


\begin{tabular}{lccl}
\hline $\begin{array}{l}\text { Name, location in Italy } \\
\text { (foundation year) }\end{array}$ & $\begin{array}{c}\text { Number of } \\
\text { generations }\end{array}$ & Core business and values & Interviewed \\
\hline Cantine Ferrari & 3 & Founded in 1902 in Trento by Giulio & Entrepreneur
\end{tabular}

\section{6}

Trento (1902)

3

Ferrari, it is the leading classic method winery in Italy. The Lunelli family, who has been leading it since 1952, controls every phase of production, from earth to table, operating with passion and respect thanks to sustainable mountain agriculture. Ferrari wine is considered an ambassador to the world for the Italian art of living

Fratelli Alinari

Florence (1852)

The oldest firm in the world still operating in the field of photography and image communication. The heritage of over five million photographs documents the history of Italy and the world from the mid-1800s to the present day: art, culture, industry, society and landscape

Keyline-Bianchi Group Conegliano, Treviso (1770)

Maserati

Modena (1914)

Picchiani e Barlacchi Florence (1902)

Table 2.

the increasingly competitive global context of the design and production of mechanical and electronic keys and duplicating machines. It is a leader in high-quality transponder car key technology. It is Italian: strongly linked to the culture of the area, faithful to its origins and the values of strength, passion and creativity

Car manufacturer operating in the sports car segment of luxury sedans, present in over 60 countries, an embodiment of refinement, elegance and Italian style around the world

More than 110 years have passed since the founding of Picchiani and Barlacchi: over a century of culture and art materialised in artistic and commemorative medals, plaques, crests, trophies and many other objects made to perfection, which recall indelible events at the local, national and international levels The Picchiani and Barlacchi archive contains over 300,000 coins that reproduce national and international history in metal from the early 20th century to the 2000 s
General

manager

Entrepreneur

CEO, marketing manager

Business owners

of the candidate for succession and taking care of his/her training and progressive taking of responsibility. In the firms interviewed, the role of the family is significant in facing the challenge of digitalisation. The family members hold positions of command in the management of the strategic functions of the firm and their involvement is fundamental to reach full sharing of the entrepreneurial project; in particular, the projects connected to digitalisation. Each episode of such sharing represents strength and increases the motivation to continue the "journey together". The respondents highlighted that the family, from 
generation to generation, has favoured innovation, while still respecting tradition, and has always been the guarantor of corporate culture and values. In the history of the respondents, the imprint of the founder emerged strongly, whose testimony cannot be deleted because in it there could be found the values, entrepreneurial spirit, vision, tenacity, passion, desire to experiment, curiosity and experience passed on to those who subsequently led the firm, keeping its roots alive. Cantine Ferrari recalled that

The founder passed the passion on to his children, and pointed out that

Without the strong idealism of the founder and of those who lead the firm, a long-lived firm could not have been started and could not have survived.

Dreaming means seeing a certain role in society, regardless of what reality seems to commonly and concretely suggest: "The ideals implicit in a dream eludes simple rationality and allows you to design the future" (Baccarani and Brunetti, 2004, p. 93).

For this reason, Cantine Ferrari celebrated the launch of a new vintage of the iconic product of Casa Ferrari, the Giulio Ferrari, by honouring its founder. The firm made an emotional video and spread it via all of the brand's online channels. Giulio Ferrari was a pioneer, who first sensed the extraordinary potential of his land, and spread chardonnay in Italy. His dream was to create a wine in Trentino capable of competing with the best French champagne. He promoted the values of a constant search for excellence in every detail, of control of the production process from "earth to table", an intimate link with the region and the consideration that the person is at the centre of the firm.

All respondents stated that it is "precious" to celebrate their roots and their history of over 100 years. Observing one's own history means reflecting on one's own path and continuing to evolve, remaining true to oneself (Martino, 2013). The firm's history includes not only the successes, the experiences and the knowledge acquired but also the difficulties and defeats. The history of a firm can also represent a source of inspiration for future strategies (Suddaby et al., 2010). Understanding the history is, therefore, a powerful tool for modelling and projecting the vision of the future and influencing the way the firm thinks about the future (Seaman and Smith, 2012). The growing attention on the knowledge contained in such an entrepreneurial path and the awareness of the cultural value of this heritage has persuaded many firms to record their history, giving life to many demanding projects, and this has been enabled by the potential offered by digitalisation. The narration of business stories is said to "take a variety of forms including written documents, verbal reports, artwork, spoken words, pictures, symbols, building and other artefacts" (Phillips et al., 2004, p. 636). For a long-lived firm, the potential and opportunity to narrate its roots and evolution is vast. All respondents outlined the history of the firm on their website and through images and videos spread via their online channels (e.g. Facebook, Youtube and Instagram). Further, some respondents had set down and celebrated the firm's history and spread this knowledge among the community to which they belong and to future generations by establishing a corporate museum and archive. To tell the truly unique story of the firm, the Amarelli family opened the Giorgio Amarelli Licorice Museum in the ancient palace where the firm had its headquarters, for which it received the Guggenheim Business \& Culture Award in November 2001. Engravings, documents, books, vintage photos, but also agricultural tools, everyday objects and beautiful ancient clothes testify to the life of the family that enhanced the underground branches of licorice plants that grow spontaneously on the Ionian coast. The museum is unique in the world, with the CEO stating:

The large space of the original place of production, the ancient 'Concio' (proto-industrial plant for extracting juice from licorice roots), dating back to 1731, perfectly reflects the idea of the passage of

Digitalisation and business longevity 
TQM

32,4

628 time between past and present. At its base is the 'Open Air Museum' with a truly unique exhibition of vintage industrial pieces. The smokestack with the initials of Baron 'Nicola Amarelli' rises imposingly from the roof of the Concio. Visitors are accompanied in the knowledge of the licorice processing, from the sheaves of root ready to be processed, to the modern plants for extraction, to the ancient cookers where the black licorice paste thickens and the bronze drawing process that gives it shape and thickness.

Amarelli also supported the digital reproduction of 16 textual, photographic and iconographic documents provided by the licorice museum.

The respondents highlighted that the presence of the family allowed for a long-term vision and pursuit of objectives. This is an important element to support decades-long projects and to pursue quality. In addition, the family has been able to define an adequate corporate governance system, thanks to which family and business have mutually strengthened each other, managerial logic has been developed and many valuable human resources have been attracted by offering opportunities for professional growth and career. The firms interviewed were also able to build a leadership comprised of an adequate mix of family and non-family managers developed from within and non-family managers from other firms, with complementary skills and values consistent with those of the owner family. The vision of the leadership with respect to the technological challenge is crucial to accepting digitalisation and promoting a change capable of benefiting the firm's competitiveness. The firms interviewed believe that new technologies are needed in the world of craftsmanship. Antica Dolceria Bonajuto, the oldest chocolate factory in Sicily still in operation and among the oldest in Italy, led by the Bonajuto family, rooted in the social and cultural local community of Modica for over 150 years, stated that:

An open mind is needed, which is necessary to evolve. In this world of 3D printers and since we are in a position to begin to understand what can be done, ideas have exploded in an unconditional way. We have recently made, unthinkable in the past, a Maxxi brand chocolate, which would be the brand of the National Museum of the 21st Century Arts in Rome. The 3D printing application allowed us to make only a hundred specimens, while in the past to make any brand or logo, we had to invest in $10,000-20,000$ moulds. With current technology, on the other hand, you can customise your work, do things in minimal quantities and at the same time, give much more of your creativity instead of entrusting it to others.

The actions, conditions and effects of digitalisation for the development of the long-lived firms analysed in the light of the command dimension are illustrated in Table 3.

The analysis shows the importance of sharing with family members in positions of command the development opportunities that digitalisation can bring to the firm opportunities previously unthinkable. A vision of a long-term perspective and a capacity to guide change are certainly necessary to improve the competitiveness of the firm. The participation and commitment of the family to an adequate system of governance, effective management of business succession and identification of the firm's leadership are fundamental in being able to support decades-long development projects and pursue quality, or rather, as stated by the firms interviewed, to continuously pursue survival.

Confirming the studies conducted on the propensity of long-lived firms to support their competitive development by combining drive for innovation and enhancement of tradition (e.g. De Massis et al., 2016; Filser et al., 2018; Erdogan et al., 2019), the respondents pointed out that they are investing in new technology promoting innovation through tradition. Specifically, the digital investment offered important support to craftsmanship because firms began to understand what can be done, ideas exploded in an unconditional way, internal creativity has been stimulated and work can be more easily customised.

Long-lived firms interviewed are closely linked to their roots and their iconic products are a symbol of a cultural identity that is also closely linked to that of the region in which they are 


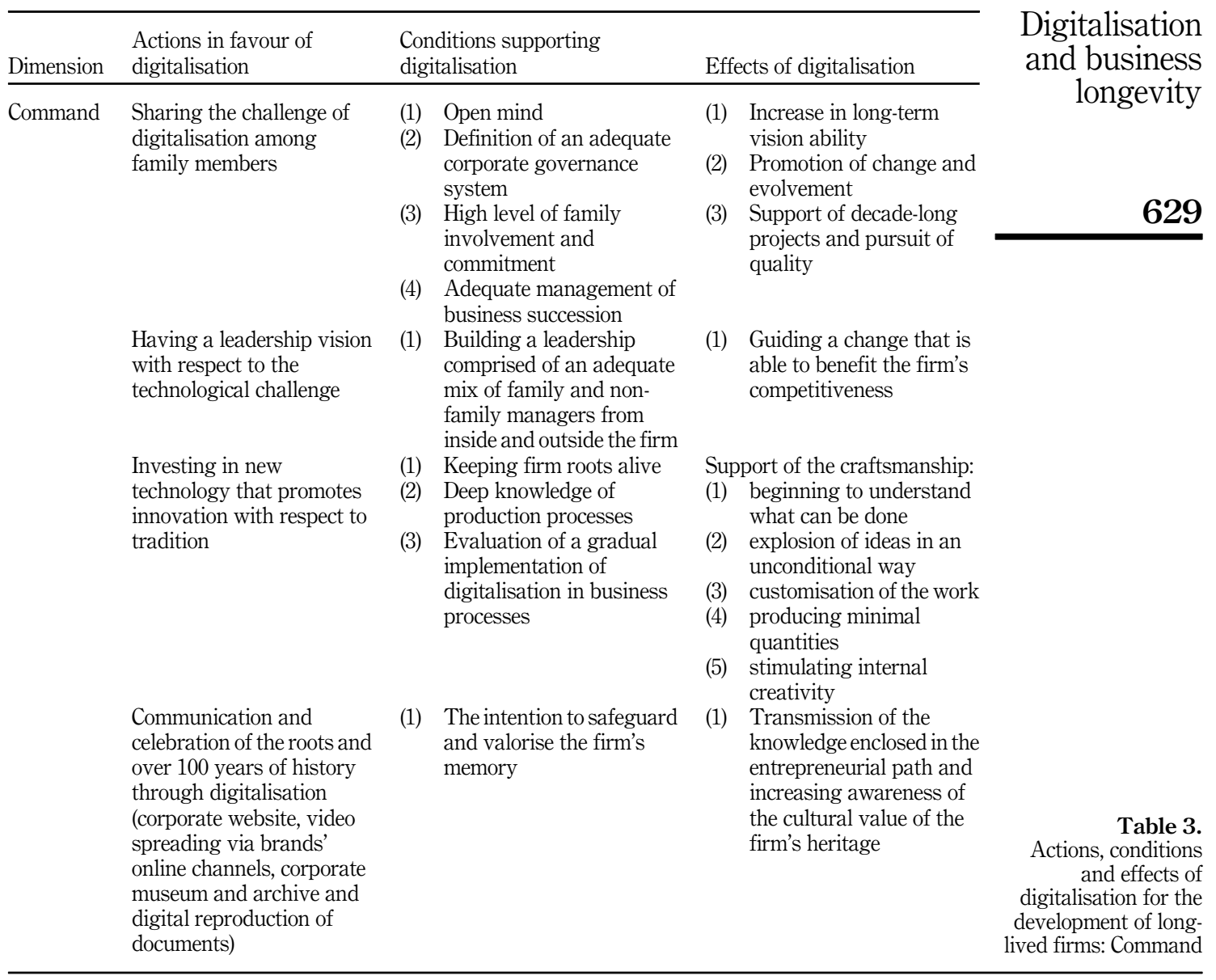

rooted. In their commitment to communicate and celebrate their long history and to safeguard corporate memory, the interviewees underlined that digitalisation represents a precious tool. For example, through corporate websites, videos spread via the brand's online channels, a corporate museum and archives and the digital reproduction of their content, the respondents supported the transmission of the knowledge enclosed in their entrepreneurial path and increased the awareness of the cultural value of their heritage. The firm's history was also valuable in defining, inspiring and legitimising a new corporate brand strategy (Iglesias et al., 2020); knowing and enhancing its own history allows the firm to appreciate the relevance of the past, and also served as a tool to build corporate identity and guide the organisation's vision. Through the communication of their history, many firms described how they managed to overcome periods of crisis by proving to be strong and resilient organisations, which created trust in stakeholders (Blomback and Brunninge, 2016). The awareness of the entrepreneur and management of the value of corporate history is important (Brunetti, 2007); they should promote processes that help to communicate and enhance corporate assets, spreading knowledge and making it significant for the cultural context. Management should 
TQM 32,4

incorporate history to support future strategy (Iglesias et al., 2020); in particular, the legitimation of the digitalisation strategy is one of the key challenges that managers need to face because it drives organisational alignment (Yeow et al., 2018).

\subsection{Continuity}

Long-lived firms remain strongly attached to their forward-looking mission. Those interviewed stated that their investments in digitalisation are aimed at increasing the efficiency of firm functions and processes, obtaining very high-quality production, supporting the brand communication strategy, enhancing the expression of a corporate style that goes beyond trends, improving the "servicescape" and strengthening and consolidating their ability to compete nationally and internationally.

With reference to the digitalisation of firm functions and processes, Maserati announced in September 2019 its plans for innovation in production, electrification and autonomous driving. The firm entered a period of intense and crucial change with a series of activities that will totally renew the product range and relaunch the brand. All the new Maserati models will be developed, engineered and produced entirely in Italy and will adopt hybrid and battery electric propulsion systems capable of providing both high innovation and high performance, typical of the brand's DNA.

Specifically, Maserati made an extraordinary investment in its Giovanni Agnelli Plant near Turin (Italy), where it produces the largest four-door sports sedan, the Ghibli executive sedan. This investment consisted of the implementation of an innovative digital technology, conceived and designed in collaboration with Siemens (the firm). Indeed, Maserati CEO detailed that:

\footnotetext{
Maserati has invested in the development of vehicle components with the Siemens NX software, in the efficient automation of the production plant with the TIA Portal engineering framework, in the simulation of production processes thanks to the Tecnomatix software that can highlight possible cost savings, and in the planning, optimisation and simulation of complex processes during the production phase with the MES Simatic IT software.
}

At the same time, these investments allowed the firm to respond to the important challenge of achieving efficient, flexible, personalised, economic and high-quality production, as well as the challenge of introducing new models to the market at shorter intervals and of controlling a network of suppliers that is ever more complex because of the increasingly lean production. As the CEO of Maserati explained:

With Siemens's product lifecycle management software, Maserati created a 'digital twin' that played a central role in the development of the Ghibli car that was 100\% faithful to the original. Data from real and virtual models were used simultaneously to optimise processes. In this way, Maserati has reduced costs and also the time for product development (by $30 \%$ ).

It should be considered that wind tunnel tests are elaborate and expensive and represent an essential physical process for optimising the aerodynamics of car bodies. The use of a digital twin has made it possible to inform virtual testing with measured data from a few real-life wind tunnel tests. As virtual tests are faster and cheaper, the company achieves the advantage of reducing costs and the opportunity to evaluate further developments.

This technology has allowed Maserati to improve the characteristics and performance of the car and the understanding of the customer experience in the passenger seat, as the firm can now "model the design and see what it looks like, model how the door is going to sound, what the exhaust is going to sound like, what rain sounds like when it hits the roof".

Thanks to the innovative digitalisation of the production process, the company can create different models along the same production line, customising the design of each product according to the customer's requests. 
From the very beginning, technological innovation has been one of the founding elements of Fratelli Alinari's mission. Management of the various steps from analogue to digital, decades-long participation in technological development projects applied to photography and experimentation with the potential of digital for the enhancement and dissemination of content have allowed the firm to offer cutting-edge design skills. The know-how ranges from advanced research systems on a non-semantic basis, to the use of content on different platforms and devices, to the creation of digital events with multiprojection and architectural mapping, to 3D technological experiments related to photography. At the centre of each project, the focus remains on new content that stands out for its quality and photographic uniqueness. Regarding the firm's ability to create highquality products through the use of sophisticated digital technologies, the general manager of Fratelli Alinari underlined that:

Using a specially designed digital camera, the firm manages to make reproductions of the highest quality, with a 100 megapixel CMOS sensor. The legendary Schneider Kreuznach lenses are able to guarantee the highest photographic quality in terms of resolution, precision in focusing and chromatic fidelity. Moreover, through the stiching [sic.] technique, by taking numerous shots (gigapixels), it is possible to create large images, even starting from small ones. The entire workflow guarantees maximum quality and productivity thanks to automatic recognition systems such as edge trimming, geometric alignment, and so on.

In 1970, Amarelli completed a modernisation process that, in 1987, was awarded the gold medal of the Italian Chemical Society for combining artisan tradition and cutting-edge technologies. All production cycles are computerised to optimise performance and safety, but the final phase of juice concentration continues to be entrusted to the experience of the "licorice master", a title handed down from father to son. As Amarelli's CEO said:

The result is a very high-quality, totally natural licorice, without additives or sweeteners, with a pleasant taste and inimitable flavour, which has made our firm a world leader in the field of pure licorice.

The investments in digitalisation made by the long-lived firms interviewed included their brand communication strategy. Biscotti Gentilini developed a social strategy to increase brand awareness and promote fan involvement thanks to numerous positive comments from the brand's passionate fan base, whose active participation increases the curiosity of new fans. As the general manager stated:

We stimulate user interaction with surveys that compete with their favourite products. These offer an opportunity to give information about products, their characteristics and how to find them.

Maserati supports its brand via the communication of various special events and initiatives; for example, by designing the \#MaseratiBeat format - a branded entertainment project between the online and the offline - with the aim of recounting the opening of MaseratiHouse in Milan and organising \#MaseratiMusicExperience, through musical and exclusive events.

As part of the communication campaigns carried out with increasing incisiveness on social channels, the long-lived firms interviewed expressed a corporate style that goes beyond trends. Cantine Ferrari highlighted this aspect in a particular way. Regarding the Ferrari Trento international communication campaign, "The Italian Tag", with a double reading - the Italian label (tag) of the Ferrari Trentodoc and a social tag to underline moments of conviviality - the entrepreneur pointed out that:

The multi-subject campaign told in a contemporary way the joy of living and sharing, also via social media, the Italian lifestyle and drinking. The product is the protagonist in each glass and becomes the social enabler of each story. The goal is to target a metropolitan and dynamic consumer target that creates a thousand other consumption opportunities outside of the classic ones.

Digitalisation and business longevity 
TQM 32,4

A further digitalisation investment planned by some firms interviewed concerned the improvement of the servicescape. In this regard, Amarelli's CEO reported that:

For the licorice museum we have created a digital signage. Three vertical and two horizontal information totems, one of which is a touch-screen to browse the Amarelli product catalogue.

The actions, conditions and effects of digitalisation for the development of the long-lived firms analysed with regard to the continuity dimension are presented in Table 4.

In line with the studies conducted in the literature (Hicks and Hegde, 2005; Sebastian et al., 2017), the firms analysed for this study pointed out that adequate implementation of innovative digital methodologies and technologies improve and optimise business processes, making them more efficient and effective. In addition to changing the management and organisation of the firm, digitalisation affected the firms' business model, the way they operate, and their interactions with stakeholders (Kiel et al., 2016, referring to Kagermann et al., 2015). This result confirms those of Rachinger et al. (2018), Coupette (2015), Loebbecke and Picot (2015) and Ernst \& Young (2011), who stated that the effect of digitalisation can present itself in the form of a reconfiguration or extension of established business models.

The respondents had various experiences in the field of digitalisation. For some, digitalisation represented a necessary and obligatory path to face the incessant competitive challenges to which they are subjected. Some had digitalised all corporate functions through all levels of their processes: from the design of product lifecycle management software and the automation of the production plant to the planning, optimisation and simulation of processes during the production phase. This is the case, for example, for Maserati, which experimented in its Giovanni Agnelli Plant with the implementation of software and an engineering framework developed with the collaboration of a business partner. Thanks to their investment in digital innovation, the analysed firms could develop new products characterised by high innovation and performance, reduce their time to market, increase the customisation of their design and improve their understanding of the customer experience. These elements of success have also been underlined by previous studies (Coupette, 2015; Kagermann et al., 2015; Loebbecke and Picot, 2015). They are the result of a decades-long commitment to technological development projects applied to the product, as supported, for example, by Fratelli Alinari. They are achievable if the firm constantly focuses on new content that increases product quality and uniqueness (Rachinger et al., 2018).

In particular, all respondents projected the development of their social brand communication strategy, which allowed them to strengthen the relationship with customers, transmit more information about products and stimulate participation, increase brand awareness, promote the involvement of the fan, and become an ambassador of the Italian lifestyle, with the product as the social enabler of each story.

\subsection{Community}

In some of the firms analysed, digitalisation had a strong impact on job management. The new digital systems increased the flexibility of employees, enabling them to operate physically outside of the workplace and at different times. They offered firms the opportunity to develop their skills and to facilitate customer management by improving the business offer.

Fratelli Alinari developed its skills in digital restoration, with the general manager underlining that:

Over the years, our group of experts has gained a profound ability to better evaluate how to retouch and professionally remove dirt and scratches, how to balance colour, how to restore portions of lost images, and so on. 


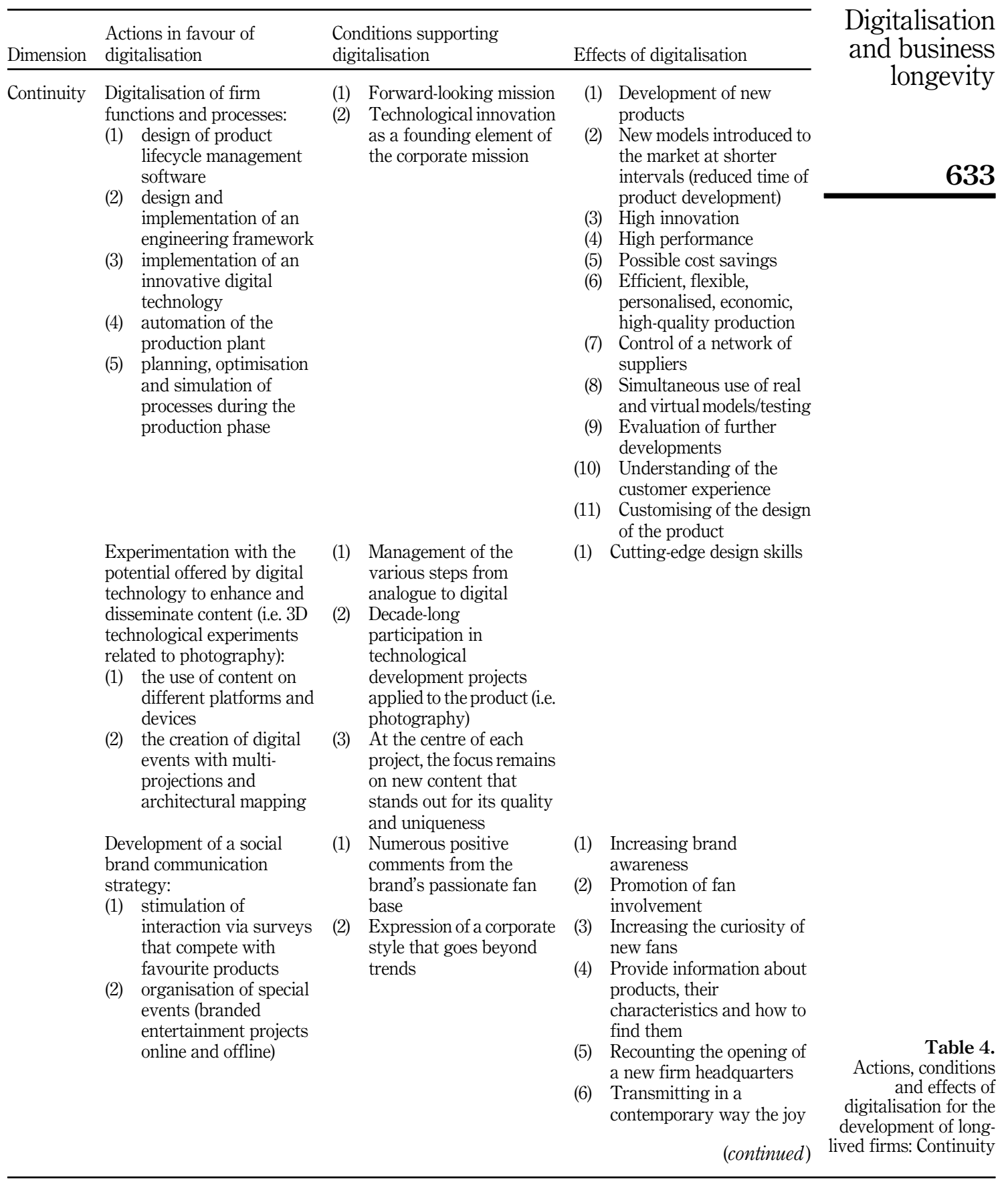




\section{4}

The creation of digital

Table 4. signage (i.e. information totems) of living and sharing the Italian lifestyle and drinking

(7) The product becomes the social enabler of each story

(8) Catching a metropolitan and dynamic target consumer, which creates consumption opportunities outside the classic ones

(1) The improvement of the servicescape

Keyline invested in the training and continuous updating of internal digital skills, aiming to enhance the technological skills that allow them to identify, evaluate, use, share and create content using information technology and the internet. Specifically, the firm's attention to digital transformation has concerned the creation of code and the development of software systems for artificial intelligence. As the world of technology is constantly evolving, digital skills are destined to change rapidly over the years (Gonzalez Vazquez et al., 2019; Lee and Falahat, 2019). In particular, the firm strengthened its design and research offices that apply digital technologies to the request for security and gave a strong boost to corporate innovation in the field of new generation duplicators. In fact, as the entrepreneur reported:

Thanks to the research and development department, the firm has created duplicators equipped with artificial vision systems capable of detecting the key encryption in less than a second. Among these, a machine, the first in the world, which sequentially performs the decoding and code encryption of high-security keys. Another important result of the corporate researchers concerns a reader for the recognition of key profiles and their location on the shelves. This allows specialists and 'do-ityourself centres' to quickly locate the raw key to be duplicated. Another important novelty, always the result of the firm's internal research skills, is the electronic duplicator for copying, decoding and encrypting flat, laser and punched keys in a single solution.

Torrini Manifattura Orafa emphasised the craftsmanship of its employees, an expression of the firm's ability to blend tradition and innovation in a unique and typical way. The laboratory, with its original Florentine artisan connotation, entrusted inspiration and art to its masters of work and supported their updating of new technologies, enabling them to create models of greater precision and "in step with the times".

The actions, conditions and effects of digitalisation for the development of the long-lived firms examined in this paragraph are presented in Table 5.

According to the studies conducted by Arnold et al. (2016) and Kiel et al. (2017), which highlighted the importance of businesses possessing additional competences and know-how in order to offer new services or solution packages, respectively, the long-lived firms interviewed saw as highly relevant the ability to build and create the know-how required to seize digitalisation opportunities. They stated that they enhanced the technological skills of their internal community by investing in employees' training and continuously updating digital skills without neglecting craftsmanship. Thanks to these competencies, they were able to evaluate, share and create content using information technology and the internet and to create products of greater precision, in step with the times and inspired by craftspeople with valuable artistic abilities. 


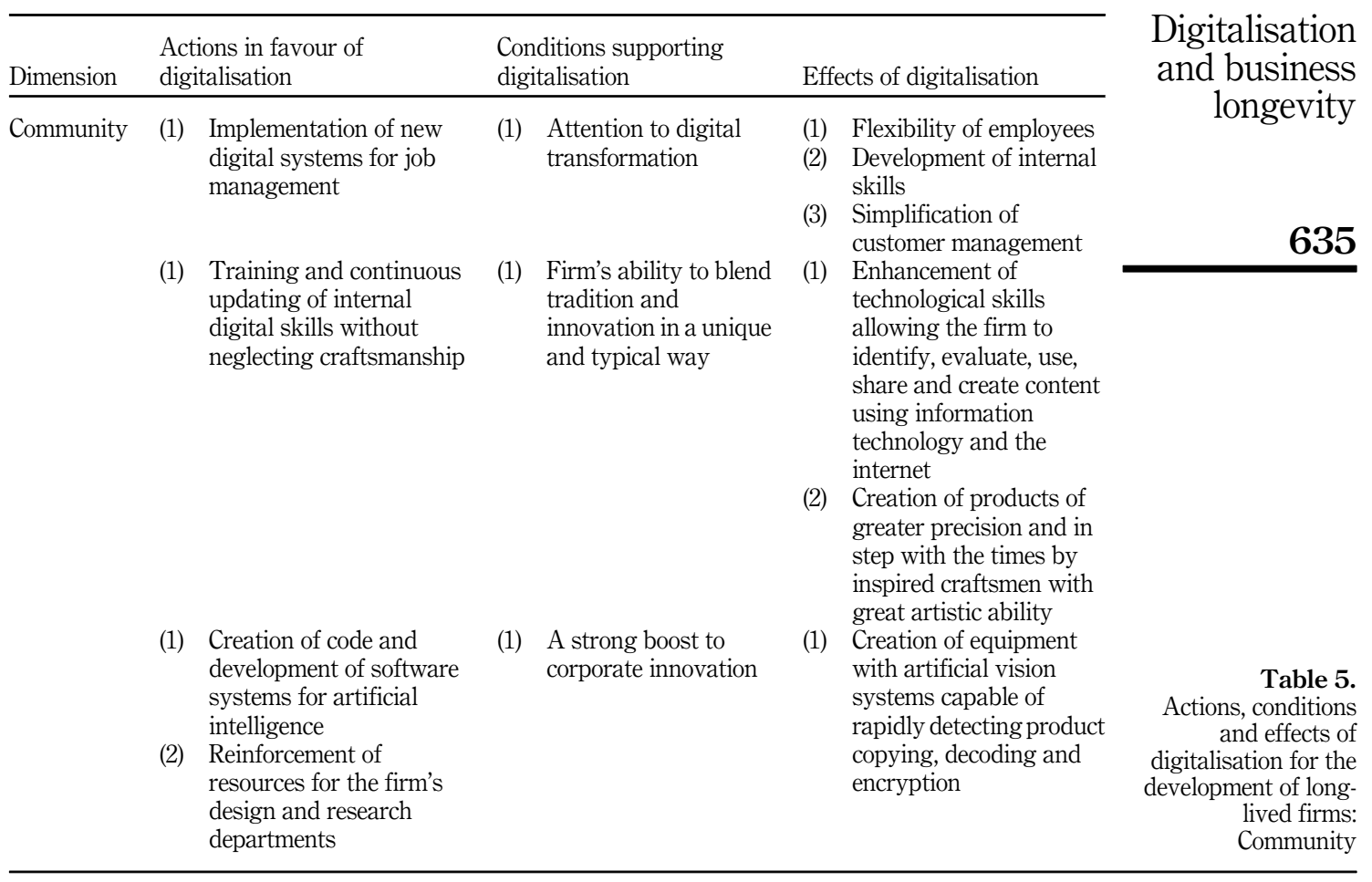

\subsection{Connection}

Regarding the establishment of long-lived external relationships with clients, suppliers, local communities, public and private institutions and associations and other regional actors, the firms interviewed highlighted that many digitalisation projects had been conceived and developed in collaboration with partners, creating alliances and synergies that have proved very valuable for competing efficiently and effectively on the global market. In this regard, Maserati, with a partner, developed Industry 4.0 capabilities at the Giovanni Agnelli Plant. They changed the way the production robots worked and optimised their positioning on the production line so they, and human staff, do not make unnecessary movements. Being able to digitally design the facility also helped because the repositioning of machinery took much less time, reducing downtime, and later increased throughput of the Ghibli alone threefold. As stated by Fiat Chrysler Automobiles' manufacturing engineering and general assembly project manager, who supervised the installation of the new production lines, "The challenge was to integrate two new assembly lines into an existing facility."

To get into the market as quickly as possible, the production experts had to start working on the new lines while the new Maserati models were still in the design phase. Maserati made use of Siemens's digital manufacturing solution for this parallel development of car and production facilities. Moreover, the manager stated that:

Maserati design engineers rapidly went through different modification scenarios of the new models over and over again. Accordingly, we had to continuously adjust the production facilities. The Tecnomatix tools helped us analyse how the changes to the car design affected production, in order to adapt the facilities and production processes appropriately. 
TQM

32,4

636

The partnership also involved suppliers in the supply chain connected to the data stream. The firm then developed a very important partnership for the management of the brand's digital strategy, digital advertising, the production of digital content, the management of promotional campaigns and analytics services. The goal was to improve the customer experience across all digital channels, maintaining the elegance and style that distinguish the brand, increase sales worldwide and extend brand equity internationally. The marketing manager said:

We are proud of the level of customer experience we offer, but at the same time, we are constantly striving to improve every interaction with our current and potential customers. A high-quality brand experience positively transforms our relationships with customers; for this reason, we want to get in touch with our customers significantly through all possible channels, from the media to after-sales assistance. Our partner is an actor capable of holistically managing the contact points between Maserati and its customers, with whom the company aims to create an authentic, continuous, coherent interaction.

The firm has also established collaborations with influencers of international relevance. In this regard, the marketing manager underlined two important influencer marketing projects promoted for the enhancement of the brand:

With Maserati \#EscapeFrom TheCity and Maserati \#Eastagram projects, travel storytelling has been developed, from Italy to Eastern Europe, on board new Maserati models, with photo shoots in the most representative places in each country. For each project, we took care in the selection and involvement of top international influencers.

Even Biscotti Gentilini involved prominent influencers in its brand communication strategy, especially the most followed food bloggers, with whom it produced quality photos reported in the posts on its recipes, stimulating sharing.

The communication concept developed by Cantine Ferrari was also supported by a digital public relations activity to enhance the brand's numerous events and partnerships, with targeted actions and ad hoc content. The firm has also created two influencer marketing campaigns: \#BollicineTime, refined storytelling for the launch of Perlè Bianco culminating in an exclusively white party at Villa Necchi Campiglio in Milan, and \#FerrariFrames of Italy, a photographic journey that incorporates some of the most popular locations in Italy and aims at presenting Cantine Ferrari as an ambassador of the Art of Italian Living and the luxury of Made in Italy.

For respondents, it is also important to participate in initiatives aimed at enhancing the competences of a region and able to promote social inclusion and cohesion based on a strong sense of identity. In this regard, the owners of Picchiani and Barlacchi noted that their firm was selected for its excellence, as handed down for generations, which was to be publicised to those coming to Italy for the universal exhibition in 2015. Thus, the firm participated in a project of the Florence Chamber of Commerce aimed at recreating a narrative of the third millennium, in which Florence could present itself to the world with contemporary language, entrusting the storytelling not to the frescoes of the churches and domes, but to visual technology and interactivity with the viewer (https://www.picchianiebarlacchi.it/i_domepicchiani-e-barlacchi/).

We are pleased that a projection has been dedicated to us inside the I_Dome, the hi-tech dome installed in the Courtyard of the Palazzo Vecchio (in Florence) where the story of the city's know-how and emblematic places flowed, seen from a new and exciting perspective, an opportunity to get to know a city capable of combining artisan tradition and digital avant-garde.

Inside the Dome, in fact, visitors were given the feeling of being in another place, without having moved. Picchiani and Barlacchi said that in order to obtain this effect, six video cameras filmed simultaneously but separately and from different angles the scenes, from 
which an "equirectangular" video was then built. In this video, all scenes were harmonised, and thanks to eight latest-generation projectors, a $360^{\circ}$ video was produced. The viewer merely had to choose which side to look at to browse through the sights of the city, as if this was a real exploration.

Actions, conditions and effects of digitalisation for the development of the long-lived firms analysed with reference to the connection dimension are indicated in Table 6.

The results showed that the conception and the development of digitalisation projects and Industry 4.0 capabilities, able to increase in efficiency and efficacy the firms' competitiveness in the global market, are supported by developing a partner network to source competences and resources.

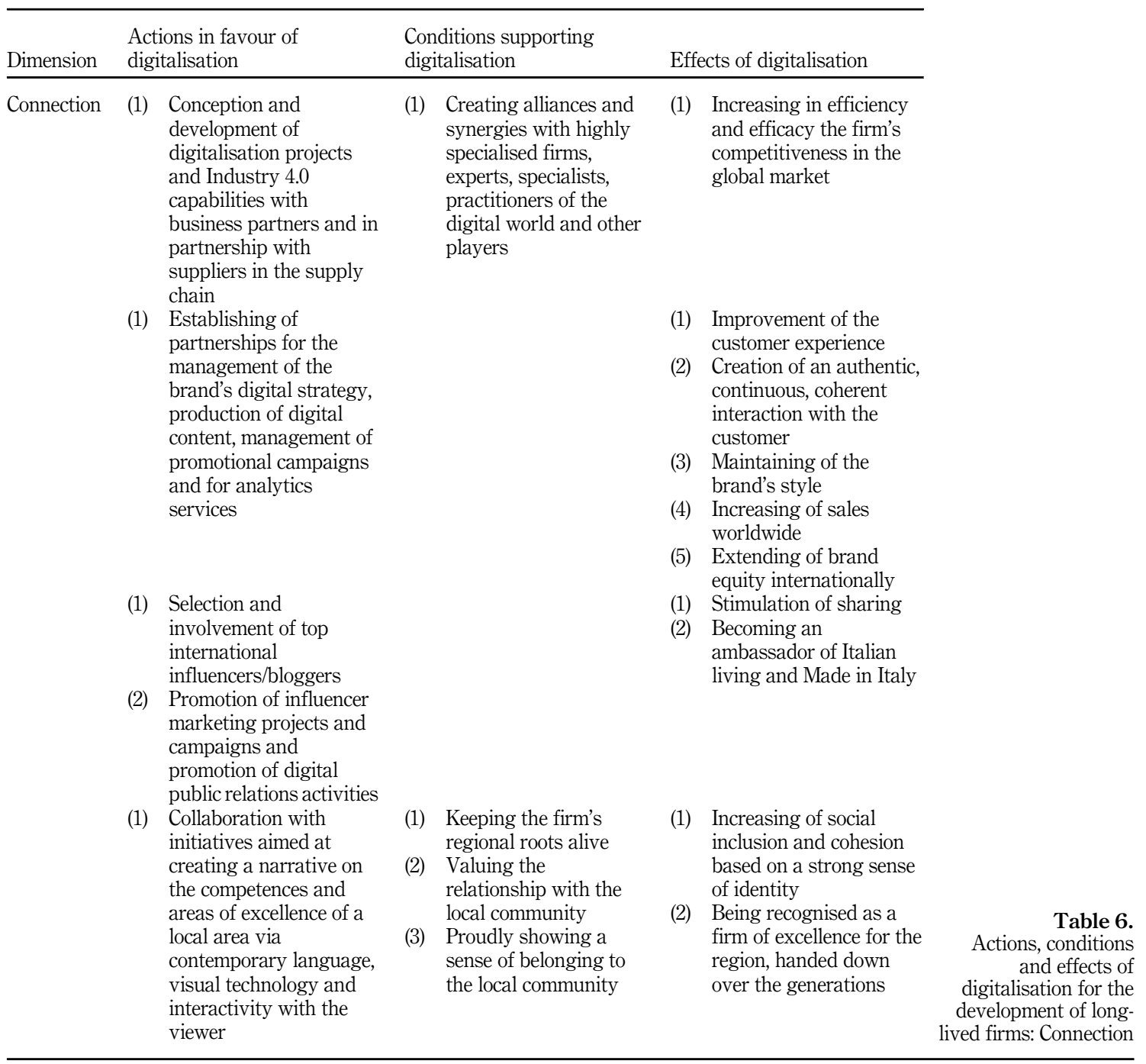

Digitalisation and business longevity 
TQM

32,4

638

Specifically, interview respondents described their engagement, with increasing intensity, in collaboration with partners, both internal and external to their sector, which did not compete with each other.

The partnerships established did not only pertain to the processes of product development but also the management of the brand's digital strategy and promotional campaigns. In this regard, the respondents stated that they selected and involved top international influencers and bloggers, with whom they promoted digital public relations activities and projects that stimulated sharing, favoured an authentic, continuous, coherent interaction with customers, valorised the brand's style and extended brand equity internationally.

Moreover, the long-lived firms interviewed engaged in the development of close relationships with the local community and belonged to various associations of local, national and international relevance, as they were aware of the value that associations have for affirming and developing ethical business values and pulling together different firms' experiences. The respondents noted that they were open to dialogue and committed to the creation of conditions of harmony and accord to support shared actions with various local actors and associations. They recognised the region for its role as a facilitator/coordinator of resources and economic activity, with a view to harmonising with the cultural and natural traditions of the place (Maizza, 2013). All respondents demonstrated a proud sense of belonging to the local community. From this perspective, the firms analysed considered their economic development as a goal that would be fully achieved when it is combined with other factors that relate to the region on which they stand and where they are recognised as a source of excellence and traditions handed down over the generations: the improvement of quality of life, the preservation of the beauty of the landscape, the optimisation of available resources and social growth are aims to share, and, in this regard, digitalisation can offer valuable support (Afonasova et al., 2019).

\section{Implications}

This exploratory study provides theoretical and practical implications. In particular, this research contributes to the theory in the following two ways. First, it combines two research streams that have, to date, been separated in terms of analysis: digitalisation and business longevity. Prior research on digitalisation has mainly examined the technological standpoint (Liao et al., 2017), by reviewing or surveying a specific research topic such as cloud technologies (Zhan et al., 2015), integration technologies (Bangemann et al., 2016; Schmidt et al., 2015), smart factories (Shrouf et al., 2014; Hozdić, 2015) and smart manufacturing (Kang et al., 2016). Scholars have also highlighted its potential benefits in terms of cost reduction, productivity, quality, customer satisfaction and even in healthcare and environmental performance (Kolberg and Zühlke, 2015; Lu, 2017). On the other side, previous longevity studies have mainly focused on the identification of longevity factors that enable business continuity and competitiveness (e.g. Collin and Porras, 1994; De Geus, 1997; Miller and Le Breton-Miller, 2005; Stadler, 2007; Galadanchi and Bakar, 2018). This research contributes to enriching qualitative studies on digitalisation of long-lived firms in relation to longevity factors highlighted by Miller and Le Breton-Miller (2005), which include the dimensions of command, continuity, community and connection. The application of this model suggests that although all long-lived firms have certain common priorities - such as the challenge of digitalisation - each designs its own combination of these priorities to allow for the best outcome from the chosen strategy.

Second, this study extends the general knowledge on the digitalisation of long-lived firms that has been proposed in the literature (e.g. Hicks and Hegde, 2005; Sebastian et al., 2017; Sharma and Dixit, 2017; Erdogan et al., 2019) by highlighting actions, conditions and effects of digitalisation for the long-lived firms' development and providing empirical evidence on how these activities can be carried out by the firms themselves. 
From the managerial point of view, this research is also useful for long-lived firms' managers who want to orient their firms towards development from a competitiveness perspective. Three practical implications are proposed. First, all long-lived firms are aware that their competitive advantage is mainly based on the craftsmanship of the product offered, on the careful attention to detail and on the pursuit of excellence; these potentials cannot be threatened by the forced pursuit of an unweighted digital innovation. Thus, it is fundamental to invest in the development of increasingly strong skills at every level, which allows interaction with the rapid evolution of the context. In fact, it is essential for top and middle management to be able to understand how digitalisation can be effectively implemented within a specific long-lived firm. All these firms are fascinated by digitalisation and the potential it incorporates, but there is no uniform response to this challenge. Some long-lived firms have a drive towards digitalisation that involves different areas of corporate activity, while others are more measured in their response. However, all have an aim in common - to grasp the potential competitive advantage arising from digitalisation to improve overall competitiveness.

Second, the role of the family, its vision of the digitalisation process for its long-lived firm and the need for managers to maintain a continuous dialogue with the family are fundamental aspects of continually redesigning and reconfiguring business processes to strengthen firm competitiveness.

Third, another important aspect is the ability to strengthen and enhance the network of relationships of each long-lived firm to synergistically improve the skills that favour an effective approach to digitalisation, not rushed or driven by imitation, but aware and fruitful for competitive development.

\section{Conclusion, limitations of the study and future research directions}

This study explored the contribution of digitalisation to long-lived firms' development by providing actions, conditions and effects from a competitiveness perspective. More specifically, the digitalisation implemented by the analysed firms contributed in different ways: (1) to improve the efficiency and effectiveness of their business processes, (2) to enhance the understanding of the customer experience, (3) to support their craftsmanship and the transmission of the knowledge incorporated in the entrepreneurial path, (4) to increase awareness of the cultural value of the firms' heritage, and (5) to develop cutting-edge design skills by experimenting with content on different digital platforms and devices.

As also argued by previous scholars (Sebastian et al., 2017), the results of this research highlighted that digitalisation is an important challenge for long-lived firms to increase their competitive advantage in the globalised marketplace. It is possible to identify digitalisation choices inherent to the product, production process, corporate communication system and the methods of cultural heritage development represented by long-lived firms; these can have strategic relevance and holistically spread their effects.

This study is not free from limitations. Given the qualitative analysis examining longlived Italian firms investing in digitalisation to develop their competitiveness, this study offers a number of suggestions that cannot be generalised because of the subjectivity of the choice of the sampling, the selection of firms operating in different sectors and the small number of firms interviewed. Another limitation is the restricted number of informants included from each analysed firm.

All these limitations could be addressed in future research. In this regard, one interesting advance is connected to the extension of the analysis to a larger number of long-lived firms and to those operating in the same sector to better understand differences and similarities among their approaches, strategies, the intensity of implementation of digital and innovative technologies, critical issues, opportunities and benefits. Moreover, it is important to interview
Digitalisation and business longevity 
TQM

32,4

more key informants responsible for digitalisation from each firm to facilitate the triangulation of data (Jack and Raturi, 2006) and gain more insights into the digitalisation of business processes. Further, deepening the study of long-lived firms located in regional contexts other than Italy would allow an evaluation of the effective influence of environmental background on the strategic orientation to digitalisation. A further interesting aspect to be explored concerns the ways in which long-lived firms arrive at the development of digitalisation paths, considering in this regard the importance of being part of pertinent associations.

\section{References}

Afonasova, M.A., Panfilova, E.E., Galichkina, M.A. and Ślusarczyk, B. (2019), "Digitalization in economy and innovation: the effect on social and economic processes", Polish Journal of Management Studies, Vol. 19 No. 2, pp. 22-32.

Albrecht, K. (2003), The Power of Mind at Work: Organisational Intelligence in Action, American Management Association, New York, NY.

Amankwah-Amoaha, J., Ottossonb, J. and Sjögrenc, H. (2017), "United we stand, divided we fall: historical trajectory of strategic renewal activities at the Scandinavian Airlines System, 19462012”, Business History, Vol. 59 No. 4, pp. 572-606.

Arnold, C., Kiel, D. and Voigt, K. (2016), "How the industrial internet of things changes business models in different manufacturing industries", International Journal of Innovation Management, Vol. 20 No. 8, pp. 1-25.

Aronoff, C. (2004), "Self-perpetuation family organization built on values: necessary condition for longterm family business survival", Family Business Review, Vol. 17 No. 1, pp. 55-59.

Baccarani, C. and Brunetti, F. (2004), Dalla penombra alla luce: un saggio sul cinema per lo sviluppo manageriale, Giappichelli, Torino.

Bakr, I.A., McGuire, J. and Soufani, K. (2009), "An empirical investigation of factor contributing to longevity of small family firms", Global Economy \& Finance Journal, Vol. 2 No. 2, pp. 1-21.

Bangemann, T., Riedl, M., Thron, M. and Diedrich, C. (2016), "Integration of classical components into industrial cyber-physical systems", Proceedings of the IEEE, Vol. 104 No. 5, pp. 947-959.

Bates, T. (1990), "Entrepreneur human capital inputs and small business longevity", The Review of Economics and Statistics, Vol. 72 No. 4, pp. 551-559.

Blind, K. (2001), "The impacts of innovation and standards on trade of measurement and testing products: empirical results of Switzerland's bilateral trade flows with Germany, France and the UK", Information Economics and Policy, Vol. 13, pp. 439-460.

Blomback, A. and Brunninge, O. (2016), "Identifying the role of heritage communication: a stakeholder-function framework", International Studies of Management \& Organization, Vol. 46 No. 4, pp. 256-268.

Brüderl, J., Preisendörfer, P. and Ziegler, R. (1992), "Survival chances of newly founded business organizations", American Sociological Review, Vol. 57 No. 2, pp. 227-242.

Brunetti, F. (2007), "Corporate history in a managerial perspective", Total Quality Management, Vol. 18, pp. 109-117.

Burgelman, R. and Grove, A. (2007), "Let chaos reign, then rein in chaos-repeatedly: managing strategic dynamic for corporate longevity”, Strategic Management Journal, Vol. 28 No. 10, pp. 965-979.

Buzzavo, L. and Gatti, G. (2012), Strategie di lunga vita d'impresa. Aziende familiari centenarie tra innovazione e tradizione, Franco Angeli, Milano.

Carney, M., Gedajlovic, E. and Strike, V.M. (2014), "Dead money: inheritance law and the longevity of family firms", Entrepreneurship: Theory and Practice, Vol. 38 No. 6, pp. 1261-1283. 
Cassis, Y. (1997), Big Business. The European Experience in the Twentieth Century, Oxford University Press, Oxford.

Colli, A., Iversen, M.J. and de Jong, A. (2013), "Mapping strategy, structure, ownership and performance in European corporations", in Colli, A., de Jong, A. and Iversen, M.J. (Eds), Mapping European Corporations: Strategy, Structure, Ownership and Performance, Routledge, Abingdon, pp. 1-13.
Digitalisation and business longevity

Collin, J. and Porras, J. (1994), Built to Last: Successful Habits of Visionary Companies, Century, London.

Collins, J. (2000), Good to Great: Why Some Companies Make the Leap and Other Don't, Harper Business, New York, NY.

Coupette, J. (2015), "Digitalisierung zwischen Erwartung und Implementierung”, IM+io Fachzeitschrift für Innovation, Organisation und Management, Vol. 1, pp. 69-75.

De Geus, A. (1997), The Living Company: Habits for Survival in a Turbulent Business Environment, Harvard Business School Press, Boston, MA.

De Massis, A., Chua, J.H. and Chrisman, J.J. (2008), "Factors preventing intra-family succession", Family Business Review, Vol. 21 No. 2, pp. 183-199.

De Massis, A., Frattini, F., Kotlar, J., Petruzzelli, A.M., Wright, M., Kotlar, J. and Messeni Petruzzelli, A. (2016), "Innovation through tradition: lessons from innovative family businesses and directions for future research", Academy of Management Perspectives, Vol. 30 No. 1, pp. 93-116.

Densil, W. and Oniel, J. (2010), "Factor associated with longevity of small, family-owned firms", International Journal of Entrepreneurship, Vol. 14, pp. 37-54.

Desai, P.S., Kalra, A. and Murthi, B.P.S. (2008), "When old is gold: The role of business longevity in risky situations", Journal of Marketing, Vol. 72 No. 1, pp. 95-107.

Dillman, D.A., Smyth, J.D. and Christian, L.M. (2009), Internet, Mail and Mixed-Mode Surveys: The Tailored Design Method, 3rd ed., John Wiley, Hoboken, NJ.

Eisenhardt, K.M. (1989), "Building theories from case study research", Academy of Management Review, Vol. 14 No. 4, pp. 532-550.

Emily, H., Mondher, F. and Imed, B. (2015), "The shape of digital transformation: a systematic literature review", Ninth Mediterranean Conference on Information Systems (MCIS), Samos, Greece, pp. 431-443.

Erdogan, I., Rondi, E. and De Massis, A. (2019), "Managing the tradition and innovation paradox in family firms: a family imprinting perspective", Entrepreneurship: Theory and Practice, Vol. 00 No. 0, pp. 1-35.

Ernst \& Young (2011), The Digitisation of Everything. How Organisations Must Adapt to Changing Customer Behaviour, Ernst \& Young LLP, London.

Fahed-Sreih, J. and Djounddourian, S. (2006), "Determinants of longevity and success in Lebanese family business: an exploratory study", Family Business Review, Vol. 19 No. 3, pp. 225-234.

Fernández Pérez, P. and Puig, N. (2007), "Bonsais in a wild forest? A historical interpretation of the longevity of large Spanish family firms", Revista de Historia Economica-Journal of Iberian and Latin American Economic History, Vol. 25 No. 3, pp. 459-497.

Filser, M., De Massis, A., Gast, J., Kraus, S. and Niemand, T. (2018), "Tracing the roots of innovativeness in family SMEs: The effect of family functionality and socioemotional wealth", Journal of Product Innovation Management, Vol. 35 No. 4, pp. 609-628.

Flick, U. (2005), Qualitative Sozialforschung, Eine Einführung, Rowohlts, Reinbeck bei Hamburg.

Foster, R. and Kaplan, S. (2001), Creative Destruction: Why Companies That Are Built to Last Underperform the Market-and How to Successfully Transform Them, Currency, New York, NY.

Fridenson, P. (2004), "Business failure and the agenda of business history", Enterprise \& Society, Vol. 5 No. 4, pp. 562-582.

Funabashi, H. (2009), Timeless Ventures. 32 Japanese Companies That Imbided 8 Principles of Longevity, Tata Mcgraw-Hill, New Delhi. 
TQM 32,4

Galadanchi, H.A. and Bakar, L.J.A. (2018), "A study of factors that support longevity of business enterprises”, IOSR Journal of Business and Management, Vol. 20 No. 1, pp. 53-59.

Gonzalez Vazquez, I., Milasi, S., Carretero Gomez, S., Napierala, J., Robledo Bottcher, N., Jonkers, K., Goenaga, X., Arregui Pabollet, E., Bacigalupo, M., Biagi, F., Cabrera Giraldez, M., Caena, F., Castano Munoz, J., Centeno Mediavilla, C., Edwards, J., Fernandez Macias, E., Gomez Gutierrez, E., Gomez Herrera, E., Inamorato Dos Santos, A., Kampylis, P., Klenert, D., López Cobo, M., Marschinski, R., Pesole, A., Punie, Y., Tolan, S., Torrejon Perez, S., Urzi Brancati, C. and Vuorikari, R. (2019), The Changing Nature of Work and Skills in the Digital Age, EUR 29823 $E N$, Publications Office of the European Union, Luxembourg.

Goto, T. (2013), "Secret of family business longevity in Japan from the social capital perspective", in Smyrnios, K.X., Poutziouris, P.Z. and Goel, S. (Eds), Handbook of Research on Family Business, 2nd ed., Edward Elgar Pub., Northampton, MA, pp. 554-587.

Hicks, D. and Breitzman, A. (2003), "Small serial innovators: the small firm contribution to technical change", Faculty Scholarship for the College of Science \& Mathematics, Vol. 41, available at: https://rdw.rowan.edu/csm_facpub/41.

Hicks, D. and Hedge, D. (2005), "Highly innovative small firms in the market for technology", Research Policy, Vol. 34 No. 5, pp. 703-716, available at: www.sciencedirect.com.

Houlder, D. and Nandkishore, N. (2016), "Corporate governance should combine the best of private equity and family firms", Harvard Business Review Digital Articles, available at: https:/store. hbr.org/product/corporate-governance-should-combine-the-best-of-private-equity-and-family-fir $\mathrm{ms} / \mathrm{h} 03 \mathrm{~d} 3 \mathrm{y}$ ?sku=H03D3Y-PDF-ENG (accessed 20 February 2020).

Hozdić, E. (2015), "Smart factory for industry 4.0: a review", International Journal of Modern Manufacturing Technologies, Vol. 7 No. 1, pp. 28-35.

Iglesias, O., Ind, N. and Schultz, M. (2020), "History matters: the role of history in corporate brand strategy", Business Horizons, Vol. 63 No. 1, pp. 51-60.

Iwasaki, N. and Kanda, M. (1996), "Sustainability of the Japanese old established companies", Economic Institute of Seijo University, Vol. 132 No. 3, pp. 130-160.

Jack, E.P. and Raturi, A.S. (2006), "Lessons learned from methodological triangulation in management research", Management Research News, Vol. 29 No. 6, pp. 345-357.

Jaskiewicz, P., Heinrichs, K., Rau, S.B. and Reay, T. (2016), "To be or not to be: how family firms manage family and commercial logics in succession", Entrepreneurship: Theory and Practice, Vol. 40, No. 4, pp. 781-813.

Kagermann, H., Riemensperger, F., Hoke, D., Schuh, G., Scheer, A.-W., Spath, D., Leukert, B., Wahlster, W., Rohleder, B. and Schweer, D. (2015), Smart Service Welt-Recommendations for the Strategic Initiative Web-Based Services for Businesses, Final Report, Long Version, Smart Service Welt Working Group, Berlin.

Kang, H.S., Lee, J.Y., Choi, S.S., Kim, H., Park, J.H., Son, J.Y., Kim, B.H. and Noh, S.D. (2016), "Smart manufacturing: past research, present findings, and future directions", International Journal of Precision Engineering and Manufacturing-Green Technology, Vol. 3 No. 1, pp. 11-28.

Kansikas, J. (2015), "The business elite in Finland: a prosopographical study of family firm executives 1762-2010", Business History, Vol. 57 No. 7, pp. 1112-1132.

Kiel, D., Arnold, C., Collisi, M. and Voigt, K.-I. (2016), "The impact of the industrial internet of things on established business models", Proceedings of the International Association for Management of Technology (IAMOT), Orlando, FL, May 15-19, pp. 673-695.

Kiel, D., Arnold, C. and Voigt, K.-I. (2017), "The influence of the industrial internet of things on business models of established manufacturing companies-a business level perspective", Technovation, Vol. 68, pp. 4-19.

Kim, Y. and Gao, F.Y. (2013), "Does family involvement increase business performance? Familylongevity goals moderating role in Chinese family firms", Journal of Business Research, Vol. 66 No. 2, pp. 265-274. 
Kolberg, D. and Zühlke, D. (2015), "Lean automation enabled by industry 4.0 technologies", IFACPapersOnLine, Vol. 48 No. 3, pp. 1870-1875.

Krahnke, K., Wanasika, I. and Soltwisch, B.W. (2018), "The spirit of shinise: lessons from long-lived Japanese companies”, Global Business and Organizational Excellence, Vol. 38 No. 1, pp. 6-14.

Kumar, N., Stern, L.W. and Anderson, J. (1993), "Conducting interorganizational research using key informants", Academy of Management Journal, Vol. 36 No. 6, pp. 1633-1651.

Lee, Y.Y. and Falahat, M. (2019), "The impact of digitalization and resources on gaining competitive advantage in international markets: the mediating role of marketing, innovation and learning capabilities”, Technology Innovation Management Review, Vol. 9 No. 11, pp. 26-38.

Leigh, B. (2002), "The innovator factor: a field guild to innovation", Inc. Magazine, available at: http:// www.inc.com/magazine/20020801/24451.html.

Leitch, C.M., Hill, F.M. and Harrison, R.T. (2010), "The philosophy and practice of interpretivist research in entrepreneurship: quality, validation, and trust", Organizational Research Methods, Vol. 13 No. 1, pp. 67-84.

Liao, Y., Deschamps, F., Loures, E.D.F.R. and Ramos, L.F.P. (2017), "Past, present and future of Industry 4.0-a systematic literature review and research agenda proposal", International Journal of Production Research, Vol. 55 No. 12, pp. 3609-3629.

Listri, P.F. (2006), Firenze. La storia e le imprese, Leo S. Olschki Editore, Firenze.

Loebbecke, C. and Picot, A. (2015), "Reflections on societal and business model transformation arising from digitization and big data analytics: a research agenda", The Journal of Strategic Information Systems, Vol. 24 No. 3, pp. 149-157.

Lu, Y. (2017), "Industry 4.0: a survey on technologies, applications and open research issues", Journal of Industrial Information Integration, Vol. 6 No. 2, pp. 1-10.

Lufkin, B. (2020). "The country has 33,000 businesses at least a century old. How have so many survived-and what does it mean for Japan's future?", Worklife, BBC, 12th February 2020, available at: https://www.bbc.com/worklife/article/20200211-why-are-so-many-old-companiesin-japan?ocid=twwl (accessed 20 February 2020).

Maizza, A. (2013), "Impresa, territorio, competitività: riflessioni e prospettive di ricerca", Sinergie, Italian Journal of Management, Vol. 90, pp. 11-21.

Marcus, A. (2006), Big Winner and Big Losers: The Four Secrets of Long-Term Business Success and Failure, Wharton School Publishing, PA.

Martino, V. (2013), Dalla storia alle storie d'impresa. Memoria, comunicazione, heritage, Bonanno Editore, Roma.

McDowell, W.C., Harris, M.L. and Geho, P.R. (2016), "Longevity in small business: the effect of maturity on strategic focus and business performance", Journal of Business Research, Vol. 69 No. 5, pp. 1904-1908.

Miller, D. and Le Breton-Miller, I. (2005), Managing for the Long Run: Lessons in Competitive Advantage From Great Family Businesses, Harvard Business School Press, Boston, MA.

Napolitano, M.R. and Marino, M.V. (2014), I Centenari. Long-Lived Italian Family Firms. A Storytelling Experience, Areablu Edizioni, Cava de' Tirreni, Salerno.

Napolitano, M.R., Marino, V. and Ojala, J. (2015), "In search of an integrated framework of business longevity", Business History, Vol. 57 No. 7, pp. 955-969.

O'Hara, W.T. (2004), Centuries of Success, Adams Media, Aron, Mayenne.

Parker, C. (2016), "Family firms and the 'willing successor' problem", Entrepreneurship: Theory and Practice, Vol. 40 No. 6, pp. 1241-1259.

Peter, T. and Waterman, R. (1982), In Search of Excellence: Lesson From America's Best Run Companies, Harper and Row, London.

Phillips, N., Lawrence, T.B. and Hardy, C. (2004), "Discourse and institutions", Academy of Management Review, Vol. 29 No. 4, pp. 635-652.
Digitalisation and business longevity

\footnotetext{
-
} 
TQM 32,4

\section{4}

Rachinger, M., Rauter, R., Müller, C., Vorraber, W. and Schirgi, E. (2018), "Digitalization and its influence on business model innovation", Journal of Manufacturing Technology Management, Vol. 30 No. 8, pp. 1143-1160.

Reader, D. and Watkins, D. (2006), "The social and collaborative nature of entrepreneurship scholarship: a co-citation and perceptual analysis", Entrepreneurship: Theory and Practice, Vol. 30 No. 3, pp. 417-441.

Riviezzo, A., Skippari, M. and Garofano, A. (2015a), "Who wants to live forever: exploring 30 years of research on business longevity", Business History, Vol. 57 No. 7, pp. 970-987.

Riviezzo, A., Garofano, A., Napolitano, M.R. and Marino, V. (2015b), "Moving forward or running to standstill? Exploring the nature and the role of family firms' strategic orientation", Journal of Family Business Strategy, Vol. 6 No. 3, pp. 190-205.

Rossato, C. (2013), Longevità d'impresa e costruzione del futuro, Giappichelli Editore, Torino.

Saldana, J. (2015), The Coding Manual for Qualitative Researchers, Sage, Los Angeles, CA.

Sasaki, I. and Sone, H. (2015), "Cultural approach to understanding the long-term survival of firms Japanese shinise firms in the sake brewing industry", Business History, Vol. 57 No. 7, pp. 1020-1036.

Schildt, H.A., Shaker, A.Z. and Antti, S. (2006), "Scholarly communities in entrepreneurship research: a co-citation analysis", Entrepreneurship: Theory and Practice, Vol. 30 No. 3, pp. 399-415.

Schmidt, N., Luder, A., Rosendahl, R., Ryashentseva, D., Foehr, M. and Vollmar, J. (2015), "Characterizing integration approaches. Identifying integration approach candidates for use in industrie 4.0", in IEEE(Ed.), 2015 IEEE 13th International Conference on Industrial Informatics (INDIN) Robinson College, Cambridge, 22-24 July 2015, IEEE, Cambridge, pp. 527-532.

Seaman, J.T. and Smith, G.D. (2012), "Your company history as a leadership tool", Harvard Business Review, Vol. 90 No. 12, pp. 44-52.

Sebastian, I.M., Ross, J.W., Beath, C., Mocker, M., Moloney, K.G. and Fonstad, N.O. (2017), "How big old companies navigate digital transformation", MIS Quarterly Executive, Vol. 16 No. 3, pp. 197-213.

Sharma, K. and Dixit, M.R. (2017), "Live long and prosper: the search for business longevity", Strategic Direction, Vol. 33 No. 11, pp. 1-3.

Shrouf, F., Ordieres, J. and Miragliotta, G. (2014), "Smart factories in industry 4.0: a review of the concept and of energy management approached in production based on the internet of things paradigm", in IEEE (Ed.), IEEE International Conference on Industrial Engineering and Engineering Management, Malaysia, 9-12 December 2014, IEEE, Selangor, pp. 697-701.

Silverman, D. (2011), Interpreting Qualitative Data, Sage Publications, London.

Stadler, C. (2007), "The 4 principles of enduring success", Harvard Business Review, Vol. 85 Nos 7/8, pp. $62-72$.

Stadler, C. (2011), Enduring Success. What We Can Learn From the History of Outstanding Corporation, Stanford University Press, Redwood City, CA.

Stolterman, E. and Fors, A.C. (2004), "Information technology and the good life", in Kaplan, B., Truex, D.P., Wastell, D., Wood-Harper, A.T. and DeGross, J. (Eds), Information Systems Research: Relevant Theory and Informed Practice, Kluwer Academic Publishers, London, pp. 687-692.

Suddaby, R., Foster, W.M. and Trank, C.Q. (2010), "Rethorical history as a source of competitive advantage", in Baum, J.A.C. and Lampel, J. (Eds), The Globalization of Strategy Research (Advances in Strategic Management, Vol. 27), Emerald Group Publishing, Bingley, pp. 147-173.

Taneja, S., Golden Pryor, M. and Hayek, M. (2016), "Leaping innovation barriers to small business longevity", Journal of Business Strategy, Vol. 37 No. 3, pp. 44-51.

Tàpies, J. and Moya, M.F. (2012), "Values and longevity in family business: evidence from a crosscultural analysis", Journal of Family Business Management, Vol. 2 No. 2, pp. 130-146. 
Tokyo Shoko Research, (2009), Special Edition: Whole Countrywide Survey on Companies Aged Over 100 Years, Tokyo Shoko Research Ltd, Tokyo.

Ward, J.L. (2004), Perpetuating the Family Business: 50 Lessons Learned From Long-Lasting, Successful Families in Business, Palgrave Macmillan, Basingstoke.

Wieccek-Janka, E., Mierzwiak, R. and Kijewska, J. (2016), "The analysis of barriers in succession processes of family business with the use of grey incidence analysis (Polish perspective)", Our Economy, Vol. 62 No. 2, pp. 33-41.

Yeow, A., Soh, C. and Hansen, R. (2018), “Aligning with new digital strategy: a dynamic capabilities approach", The Journal of Strategic Information Systems, Vol. 27 No. 1, pp. 43-58.

Zellweger, T.M. and Sieger, P. (2012), "Entrepreneurial orientation in long-lived family firms", Small Business Economics, Vol. 38 No. 1, pp. 67-84.

Zellweger, T.M., Nason, R.S. and Nordqvist, M. (2012), "From longevity of firms to transgenerational entrepreneurship of families: introducing family entrepreneurial orientation”, Family Business Review, Vol. 25 No. 2, pp. 136-155.

Zhan, Z.H., Liu, X.F., Gong, Y.J., Zhang, J., Chung, H.S.H. and Li, Y. (2015), "Cloud computing resource scheduling and a survey of its evolutionary approaches", ACM Computing Surveys, Vol. 47 No. 4, pp. 1-33.

\section{Corresponding author}

Chiara Rossato can be contacted at: chiara.rossato@univr.it
Digitalisation and business longevity 